\title{
Brexit: doctors' duty is to inform patients
}

\author{
Fiona Godlee editor in chief
}

The BMJ

The US news has this week been issuing a constant stream of reports on the path of Hurricane Dorian, its ferocity, timing, and likely effects of landfall. Regular government updates give advice to stock up on food, water, and drugs and instructions on when and where to evacuate. Emergency services and healthcare teams are on the scene to advise and provide what help they can.

Meanwhile the UK faces a hurricane of its own creation: a no deal Brexit with almost certain landfall in five weeks' time. But instead of clear, up to date, and objective information about the predicted scale and impact, we must rely on what can be gleaned from leaked documents (http://bit.ly/21x5cQn), while officials obfuscate and give hardly convincing assurances that all will be well.

Of course our leaders have a problem. They, not the weather, have brought the UK to this point, and they don't want to scare the horses: a true understanding of the effects of no deal would frighten the public and fuel already vocal opposition to Brexit.

But other voices, unencumbered by the need to stick to a party line, are doing their best to keep the public informed and are unanimous in their concern about the harms of no deal. In the latest of its series of Brexit briefings the BMA says that no deal will push the NHS "to the brink," leaving no area of health unscathed and with catastrophic consequences (doi:10.1136/ bmj.15343). The UK's three major health think tanks agree. In an open letter to MPs the King's Fund, Health Foundation, and Nuffield Trust say that leaving the EU without an agreement could cause significant harm to health and social care services (www.kingsfund.org.uk/publications/no-deal-brexit).
Where, ask May van Schalkwyk and colleagues (doi:10.1136/ bmj.15300), is the independent health impact assessment for a no deal Brexit? Without this, how can plans be made? How can members of the public know what they need to do to protect themselves? The authors offer a framework for such an assessment and call on the government to give an honest analysis of the threats to health.

Doctors involved in planning for no deal may find themselves in a tricky position. In a radio phone-in show this week, after a doctor whistleblower who had advised the government on drug shortages repeated his concerns, the host, cabinet member Jacob Rees-Mogg, told him that he should feel "quite ashamed" for "the worst excess of project fear" (doi:10.1136/bmj.15379).

Your employers might have told you that anything you learn in the planning process is confidential. You may even have signed a non-disclosure agreement. What if you discover, as you almost certainly will, that planning for no deal can't possibly remove the risk of worsening health or deaths from shortages of medical supplies? On BMJ Opinion Peter English and colleagues are clear about your first duty, which is to the population of patients you serve (https://blogs.bmj.com/bmj/2019/09/02/brexit-doctorsfirst-duty-in-no-deal-planning-is-to-speak-up-about-the-risksto-patients). They say, "Doctors involved in no-deal planning should explain this duty to their employers and to any partner organisations, seek assurances that any risks will be put into the public domain, and explain that if such risks are not made public, they will have a duty to do so that over-rides any duty of confidentiality."

Brexit was sold to Britain on a bus proclaiming it would be better for health. We have to tell the public that nothing could be further from the truth. 